\title{
TRADISI ZIARAH KUBUR PASCA PERNIKAHAN (STUDI KASUS KELURAHAN MANISA, KECAMATAN BARANTI, KABUPATEN SIDRAP, SULAWESI SELATAN )
}

\author{
Syandri \\ Sekolah Tinggi Ilmu Islam dan Bahasa Arab (STIBA) Makassar \\ syandri@stiba.ac.id \\ Iskandar \\ Sekolah Tinggi Ilmu Islam dan Bahasa Arab (STIBA) Makassar \\ iskandarkato@stiba.ac.id

\section{Sulaiman Kadir} \\ Sekolah Tinggi Ilmu Islam dan Bahasa Arab (STIBA) Makassar \\ sulaiman@stiba.ac.id
}

Keywords :
Islamic Law, Tradition,
Visit the Graves, Marriage
Kata kunci :

Hukum Islam, Tradisi,

Ziarah Kubur, Pernikahan

\section{ABSTRACT}

This study aimed to identify the process and purpose of the grave pilgrimage tradition after marriage in Manisa village, Baranti subdisctrict, Sidrap district, South Sulawesi, and also to examine the law of the custom in the view of Islamic law. This research employed a qualitative approach with the field study method (Field Research) and library research. The study shows that: 1. People ini Manisa village after celebrating their wedding they make grave pilgrimage in forms of such as: Determining a certain time according to the agreement of the bride and groom, preparing the necessary preparations such as water, kettles, and pandanus leaves, making ablution before going to the graveyard, praying before entering the cemetery, watering the grave with water mixed with pandanus leaves, holding the gravestone, praying for the late by reciting certain chapters finalized by surah Al-Fatihah. 2. Grave pilgrimage is one of the prescribed acts of worship but it should be in accordance with the guidance of the Prophet. As for what is found in the people of Manisa Urban Village, there are still a number of differences between what they do and what had been exemplified by the Messenger of Allah such as the determination of a special time for the grave pilgrimage, watering the grave, and seeking for blessing from the graves visited.

Penelitian ini bertujuan untuk mengetahui prosesi dan tujuan tradisi
ziarah kubur pasca pernikahan di kelurahan Manisa Kecematan
Baranti Kabupaten Sidrap Sulawesi Selatan dan juga mengkaji
hukum adat tersebut dalam pandangan hukum Islam. Penelitian ini
menggunakan pendekatan kualitatif dengan metode studi lapangan
(Field Research) dan studi kepustakaan (library research). Penelitian
ini menemukan bahwa: 1. Masyarakat Kelurahan Manisa pasca
acara pernikahan melakukan ziarah kubur dengan bentuk-bentuk
seperti; Menentukan waktu tertentu sesuai kesepakatan kedua
mempelai, menyiapkan persiapan yang dibutuhkan seperti air, ceret
dan daun pandan, berwudhu sebelum berangkat ke kuburan, berdoa
sebelum masuk di area pekuburan, menyiram kuburan dengan air



pengantin memegang batu nisan kuburan, mendoakan si mayyit dengan membacakan surah-surah tertentu dan ditutup dengan surah Al-Fatihah, 2. Ziarah kubur merupakan salah satu ibadah disyariatkan akan tetapi dalam berziarah kubur harus sesuai dengan tuntunan Rasulullah saw. Adapun yang ditemukan di kalangan masyarakat Kelurahan Manisa masih lebih banyak ketidaksesuaian dengan apa yang dicontohkan oleh Rasulullah saw. seperti adanya penentuan waktu khusus untuk ziarah kubur, menyiram kuburan dan meminta restu dari kuburan yang diziarahi.

\section{PENDAHULUAN}

Islam merupakan agama yang datang dari Allah swt. dan merupakan satusatunya agama yang sempurna. Seluruh syariat-Nya berasal dari Allah swt. Di mana syariat tersebut merupakan hukum atau aturan. Dari itulah Allah swt. mengutus Rasul di setiap kaum untuk menyampaikan dan menjelaskan seluruh syariat-Nya kepada umat manusia, sebagaimana Dia mengut us Nabi Muhammad saw. untuk umat ini. Itulah nikmat yang terbesar atas umat ini. Nikmat dan keutamaan yang tak pernah Allah swt. berikan kepada agama-agama dan umatummat sebelum ummat ini. Allah swt. berfirman dalam Q.S. al-Māidah/5: 3 .

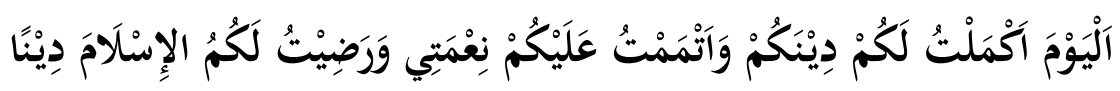

Terjemahnya: "Pada hari ini telah Aku sempurnakan agamamu untukmu, dan telah Aku cukupkan nikmat-Ku bagimu, dan telah aku ridai Islam sebagai agamamu."

Dari ayat di atas menjelaskan bahwa Allah swt. telah menyempurnakan agama Islam ini dan menjelaskan bahwa hanya agama Islamlah yang diridai di sisi Allah swt. dan tidak ada agama selainnya.

Allah swt. mengutus seorang Nabi dan juga sebagai seorang Rasul yang terakhir dari kalangan manusia, yang mana tidak ada Nabi sesudahnya di permukaan bumi. Dialah Nabi Muhammad saw. manusia termulia, pemimpin umat ini, yang bahkan seorang Michael Hart dalam bukunya (a Ranking of the Most Influential Persons in History) menempatkan Nabi Muhammad saw. sebagai tokoh utama yang paling berpengaruh. ${ }^{2}$

Islam adalah agama yang sempurna dan paripurna. Tidaklah suatu amalan yang disyariatkan melainkan telah ada dalilnya dari Nabi Muhammad saw. termasuk d iantaranya adalah ziarah kubur. Ziarah kubur disunahkan oleh Nabi Muhammad saw., bahkan dianjurkan kepada umat Islam mengunjungi (Ziarah) ke kubur orang tua, atau keluarga yang telah lebih dulu meninggal dunia. ${ }^{3}$ Ziarah dimaksud untuk menumbuhkan kesadaran agar orang yang hidup selalu ingat

'Kementerian Agama Republik Indonesia, Al-Qur'an Tajwid dan Terjemahnya (t. Cet. Jakarta: Syamil Qur'an, 2010 M), h. 142. h. 3 .

${ }^{2}$ Michael H. Hart, 100A Rangking Of The Most Influential Person In Histori, (New York, Hart Pub. Co, 1987), 
bahwa suatu saat akan merasakan kematian. Sebagaiman Firman Allah swt. dalam Q.S. Ali 'Imrān/3: 185.

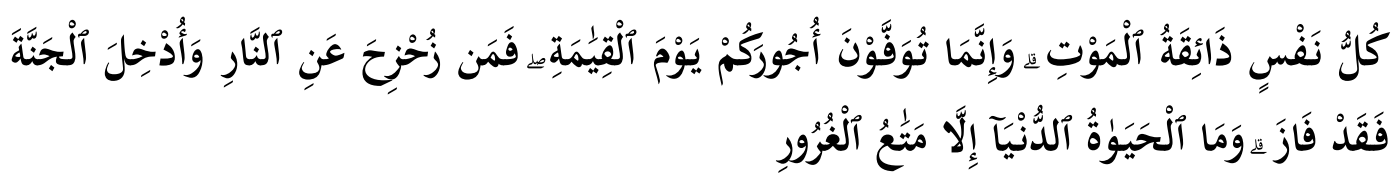

Terjemahnya: Setiap yang bernyawa pasti akan merasakan mati. Dan hanya padahari kimat sajalah diberikan dengan sempurna balasanmu. Barang siapa dijauhkan dari neraka dan dimasukkan ke dalam surga, sungguh dia memperoleh kemenangan. Kehidupan dunia hanyalah kesenangan yang memperdaya. ${ }^{4}$

Dari ayat di atas dijelaskan bahwa semua makhluk hidup yang ada di atas muka bumi semuanya akan mati dan akan dipertanggungjawabkan semua amalannya di sisi Allah swt. Adapun ziarah kubur pada zaman Rasulullah saw. hanya disunahkan bagi kaum laki-laki. Bagi kaum wanita Rasulullah saw. pernah melarangnya karena disebabkan akan menimbulkan kesedihan yang mendalam, sulit menerima takdir Allah, suka meraung-raung, teriak-teriak dan melakukan halhal bidah yang Allah swt. haramkan untuk dilakukan. ${ }^{5}$

Adapun ziarah kubur ini pada umumnya makruh bagi wanita disebabkan hal-hal yang telah disebutkan sebelumnya. Kemudian datang hadis dari Rasulullah saw. yang mengatakan kebolehan berziarah kubur bagi wanita, kebolehan dimaksud adalah rukhșah (keringanan). ${ }^{6}$

Dalam perkembangan Islam, banyak kepercayaan-kepercayaan yang muncul di kalangan masyarakat umat Islam secara khusus. Mereka memahami bahwa ziarah kubur adalah suatu kebiasaan secara turun-temurun bagi kebanyakan masyarakat yang mana awalnya hanya mengikuti dan akhirnya menjadi suatu tradisi di kalangan umat Islam.

Secara umum mereka juga memahami bahwa ziarah kubur adalah warisan dari nenek moyang yang mana mereka masih sangat kental tentang paham animisme. Animisme adalah kepercayaan kepada makhluk halus dan roh yang ada pada tumbuh-tumbuhan, hewan, gua, dan batu besar. Sedangkan dinamisme adalah kepercayaan bahwa segala sesuatu mempunyai tenaga atau kekuatan yang dapat mempengaruhi keberhasilan atau kegagalan usaha manusia dalam mempertahankan hidup. ${ }^{7}$

Awal perkembangan Islam, ziarah kubur sempat dilarang oleh syariat. Pertimbangan akan timbul fitnah syirik di tengah-tengah umat, menjadi faktor terlarangnya ziarah kubur pada waktu itu. Namun, seiring perkembangan kemajuan Islam, larangan ini dihapus dan syariat menganjurkan umat Islam untuk berziarah kubur agar mereka dapat mengambil pelajaran dari hal tersebut, di

\footnotetext{
${ }^{4}$ Kementerian Agama Republik Indonesia, Al-Qur'an Tajwid dan Terjemahnya, h. 95. h. 362 .

${ }^{5}$ Abī Dāud Sulaimān bin al-As'as al-Sijistānī al-Azdī, Sunan Abī Dāud juz III (Beirūt: Dār Ibnu Hazm, 1997),

${ }^{6}$ Muhammad bin Isā bin Surah al-Tirmiżī, Sunan al-Tirmiżī, juz I (Riyāḍ: Maktabah Ma'ārif 1417 H), h. 250.

${ }^{7}$ Tim Penyusun Kamus Pusat Bahasa, Kamus Bahasa Indonesia (t. Cet; Jakarta: Pusat Bahasa Departemen Pendidikan Nasional, 2008), h. 1829.
} 
antarannya mengingat kematian yang pasti dan akan segera menjemput sehingga hal tersebut dapat melembutkan hati mereka dan senantiasa mengingat kehidupan akhirat yang akan dijalani kelak.

Rasulullah saw. mensyariatkan ziarah kubur bagi kaum muslimin, dengan dasar-dasar yang sesuai syariat dan apa yang dicontohkan oleh para orang-orang terdahulu. Dari Buraidah bin al-Ḥushaīb al-Aslamī ra. Ia berkata, Rasulullah saw. bersabda:

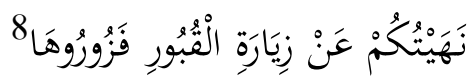

Artinya: "Aku pernah melarang kalian untuk berziarah kubur, maka sekarang berziarahlah."

Hadis di atas menjelaskan tentang pelarangan ziarah kubur di awal Islam kemudian Rasulullah saw. mensyariatkan ziarah kubur supaya manusia dapat mengambil pelajaran bahwa semua manusia pasti akan mati.

Di tengah pesatnya perkembangan ilmu pengetahuan Islam di era globalisasi ini dan hingga penyebarannya ke pelosok-pelosok dunia adalah merupakan bentuk dari perjuangan para ulama. Namun, perlu kita sadari bahwa semakin pesatnya perkembangan itu, tentu sangat berpengaruh pada kondisi ketauhidan umat Islam. Mulai dari zaman khulafâ urrā syidinn dan sampai saat ini, masih menjadi problematika umat. Misalnya, yang mana kita saksikan sendiri dalam masyarakat ataupun dalam keluarga, masalah dalam persoalan ziarah kubur, orang-orang berziarah kubur di waktu dan tempat-tempat tertentu misalnya, waktu Idul Fitri, Idul Adha, setelah melangsungkan pernikahan, hari Jumat dan waktuwaktu yang lain.

Adapun tempat tertentu misalnya, kuburan para ulama, para sunan, para tokoh penyebar Islam, atau keluarga kedua mempelai wanita dan laki-laki yang telah meninggal dunia atau orang-orang tertentu yang dianggap bisa mendatangkan berkah. Namun, yang sering didapati adalah mereka berziarah kubur dengan maksud dan tujuannya untuk beribadah kepada Allah swt. dengan menjadikan kuburan layaknya sebagai tempat beribadah, dan menganggap bahwa kuburan adalah suatu tempat yang sakral.

Dalam hal ini timbul hal-hal yang bertentangan dengan syariat, sebagai contoh, sebagian masyarakat Sidrap yang melakukan ziarah kubur hanya pada waktu dan hal-hal tertentu, sehingga menjadi adat kebiasaan di kalangan mereka. Contoh: "Ziarah kubur yang dilakukan oleh kedua pasangan suami-istri beserta keluarganya sebelum mengadakan acara dan setelah melangsungkan pernikahan dengan mengunjungi kuburan keluarganya yang telah meninggal dunia untuk meminta doa restu, pertolongan, keberkahan, dan sebagainya, sehingga adat ini sudah menjadi "Urf (kebiasaan) di tengah masyarakat suku bugis terkhusus masyarakat Sidrap."

${ }^{8}$ Abu Husain Muslim bin al-Hajajāj al-Qusyairī al-Naisābūrī, Sahạḥ Muslim (Cet. I; al-Qāhirah: Dār ibn al-Jauzī, 2009), h. 216. 
Dari penjelasan di atas, dapat dirumuskan masalah mengenai tinjauan hukum Islam terhadap tradisi ziarah kubur setelah melangsungkan pernikahan Adapun rumusan masalahnya yaitu:

1. Bagaimana bentuk ziarah kubur di kalangan masyarakat Kelurahan Manisa Kecamatan Baranti Kabupaten Sidenreng Rappang setelah melangsungkan pernikahan?

2. Bagaimana tinjauan hukum Islam terhadap tradisi ziarah kubur setelah melangsungkan pernikahan?

Untuk menjawab permasalahan tersebut, penelitian ini dilakukan dengan tujuan sebagai berikut:

1. Untuk mengetahui proses ziarah kubur di kalangan warga Kelurahan Manisa Kecamatan Baranti Kabupaten Sidenreng Rappang setelah melangsungkan pernikahan.

2. Untuk mengetahui tinjauan hukum Islam terhadap tradisi ziarah kubur setelah melangsungkan pernikahan.

3. Memberikan pencerahan, bagaimana semestinya yang harus dilakukan oleh seorang pengantin sebelum dan pasca pernikahan.

4. Diharapkan ini dapat menjadi solusi dari permasalahan yang ada di kalangan masyarakat saat ini yang berkaitan dengan ziarah kubur serta memberikan masukan dan bahan referensi sekaligus petunjuk praktis bagi peneliti menggeluti ilmu-ilmu Islam (Islamic studies) khususnya bidang fikih dan Akidah.

Penelitian atau tulisan ilmiah terdahulu yang menjadi referensi atau acuan dalam kajian ini, di antaranya:

Syaikh al-Islām Ibnu Taimiyah ra. dalam kitabnya Ziyārah al-Qubūr wa alIstinjādu bì al-Qubūr memaparkan pendapatnya tentang ziarah kubur yang disyariatkan dalam Islam bahwasanya ziarah kubur yang disyariatkan yaitu dengan mengucapkan salam kepada penghuni kubur, mendoakannya ketika mensalati jenazahnya, dan tidak meminta hajat kepada orang mati dan menyampaikan keluhannya serta tidak bertawassul kepada kuburan bahkan sebaliknya orang yang masih hidup memberikan manfaat kepada orang yang telah meninggal. ${ }^{9}$

Ibnu al-Batanji dalam kitabnya, "Bila Kuburan Didewakan." Di dalam buku ini membahas tentang tujuan ziarah kubur bahwa penghuni kubur itu tetap mengharapkan doa dan salam dari orang yang masih hidup. Berdasarkan riwayat Aisyah ra., ia bercerita bahwa setiap kali malam gilirannya, Nabi saw. Sering keluar tengah malam menuju pemakaman Baqī menyampaikan salam dan doa dan di antara tujuan berziarah kubur yang lain yaitu untuk mengingatkan pada kematian. ${ }^{10}$

Taufik meneliti tentang Persepsi Masyarakat Palakka Terhadap Tradisi Ziarah Kuburan Petta Betta'E di Kabupaten Bone (Suatu Tinjauan Teologis).

\footnotetext{
${ }^{9}$ Syaikh al-Islām Ibnu Taimiyyah, Ziyārah al-Qubūr wa al-Istinjā du bī al-Maqbūri (Cet. I; [t.t.] Dār al-Ṡahābah lī al-Tarāś, 1992 M) h. 17-18.

${ }^{10}$ Ibnu Batanji, Bila Kuburan Didewakan (t. Cet; Solo: Pustaka Arafah, 2013) h. 128-129.
} 
Dalam penelitian ini, Taufik menyimpulkan bahwa tradisi ziarah pada kuburan Petta Betta'E memiliki relasi dengan akidah Islam, karena dalam tradisi ziarah yang dilakukan memiliki proses dan motivasi yang perlu adanya pemahaman dan bahkan telah menjadi suatu yang bertentangan dalam akidah Islam, seperti mengirimkan doa, mengambil batu dan kain pada kuburan sebagai jimat, bahkan motivasi dalam menziarahi kuburan sebagai tempat untuk meminta pertolongan. ${ }^{11}$

Atas pengkajian di atas, pada penelitian ini sangat berbeda dengan penelitian sebelumnya, di mana kajian ini berfokus pada kajian tradisi ziarah kubur setelah melangsungkan pernikahan yang dilakukan oleh masyarakat di Kelurahan Manisa Kecamatan Baranti Kabupaten Sidrap Sulawesi Selatan yang belum pernah ditemukan dalam penelitian-penelitian sebelumnya.

Penelitian ini menggunakan pendekatan kualitatif dengan metode studi lapangan (field research) dan studi kepustakaan (library research) dengan analisis deskriptif. Metode penelitian ini digunakan untuk menggambarkan suatu fakta yang terjadi serta memberikan penilaian yang terjadi di lapangan melalui telaah referensi di belakang meja, setelah penelitian ini dilakukan. Penelitian kualitatif yaitu penelitian yang datanya dinyatakan dalam bentuk verbal, pengamatan dan analisis tanpa menggunakan teknik statistik (non statistik). Penelitian yang sering dilakukan dengan cara ini adalah studi kasus dan lainnya. ${ }^{12}$

Adapun kajiannya adalah menggunakan analisis kualitatif deskriptif. Hal ini bermaksud untuk memberikan gambaran sistematis mengenai suatu fenomena, gejala dan keadaan-keadaan yang terjadi serta menjelaskan secara akurat keadaan yang ada hubungannya dengan variabel-variabel yang diteliti melalui telaah kepustakaan.

Dalam penelitian kualitatif ini, peneliti melakukan pencatatan, menganalisa dan menginpretasikan keadaan yang ada dengan sebenarnya. Artinya, menghimpun informasi-informasi sesuai realitas beserta variabel-variabel yang telah ditentukan yang menjadi indikator dalam penelitian ini, yakni untuk mendapatkan data-data kongkrit tentang tradisi ziarah kubur setelah melangsungkan pernikahan pada Masyarakat di Kelurahan Manisa Kecamatan Baranti Kabupaten Sidenreng Rappang. Setelah itu dilakukan pengkajian dan analisis mendalam dan interpretif melalui telaah kepustakaan dalam proses penyimpulan hukum Islam atau fenomena yang terjadi tersebut.

Dalam penelitian ini, yang dijadikan subjek penelitian adalah warga yang beralamat di Kelurahan Manisa, Kecamatan Banranti, Kabupaten Sidrap. Penelitian ini termasuk dalam kategori penelitian lapangan dari sisi pengambilan data, yakni meneliti peristiwa-peristiwa yang ada di lapangan sebagaimana adanya, lalu kemudian dilakukan penyimpulan hukum Islam melalui telaah kepustakaan, bersumber dari Al-Qur'an, Hadis, dan pendapat ulama dalam kitabkitabnya. Berdasarkan masalahnya, maka penelitian ini digolongkan sebagai penelitian dengan menggunakan pendekatan sosiologis dan normatif.

${ }^{11}$ Taufik, Persepsi Masyarakat Palakka Teradap Tradisi Ziarah Kuburan Petta Betta’e Di Kabupaten Bone (Suatu Tinjauan Teologis), (Skirpsi, Universitas Islam Negeri Alauddin Makassar, 2018), h. 98.

${ }^{12}$ Muhammad Khalifah Mustami, Metodologi Penelitian Pendidikan (Cet.I; Yogyakarta: Aynat Publishing, 2015), h.14. 


\section{PEMBAHASAN}

Kelurahan Manisa adalah sebuah Kelurahan di wilayah Kecamatan Baranti, Kabupaten Sidenreng Rappang, Provinsi Sulawesi Selatan yang memiliki luas wilayah sekitar $17.72 \mathrm{Km}^{2}$ dengan jumlah penduduk 7.086 jiwa. Kelurahan Manisa adalah sebuah Kelurahan di Kecamatan Baranti yang berada di ujung kecamatan yang berbatasan langsung dengan Kecamatan Watang Pulu. Kelurahan Manisa terdiri dari 4 (empat) lingkungan. ${ }^{13}$

\section{Keadaan Sosial Ekonomi Masyarakat Kelurahan Manisa}

Dalam kehidupan sehari-hari masyarakat Kelurahan Manisa banyak melakukan usaha atau aktivitas untuk mencari nafkah guna memenuhi kebutuhan hidupnya sehari-hari. Pada umumnya, mata pencaharian masyarakat Kelurahan Manisa adalah beraneka ragam, mulai dari bertani, berkebun, beternak dan ada pula yang berdagang. Masyarakat Kelurahan Manisa dalam memenuhi kebutuhannya tidak berhenti pada satu pekerjaan saja, mereka yang bertani juga berternak bahkan berdagang pula, mereka pun yang sudah menjadi pegawai negeri tidak berhenti bertani.

Dari beragam mata pencarian yang dilakukan itu, yang paling dominan ialah bertani. Sawah-sawah yang terhampar luas menjadi penghasilan terbesar di kelurahan ini, beberapa masyarakat mampu mengolah hasil pertanian masyarakat yang lain dengan mendirikan pabrik-pabrik penggilingan padi.

\section{Keadaan Sosial Keagamaan}

Dalam konteks keagamaan, masyarakat Kelurahan Manisa adalah mayoritas beragama Islam, dan ada yang beragama Hindu (Tolotang). Upaya pemenuhan sarana dan prasaran kehidupan beragama pada dasarnya merupakan tanggung jawab masyarakat, karena pemerintah juga mempunyai tanggung jawab atas pembinaan kehidupan beragama pada masyarakat. Dengan demikian, pemerintah telah memberikan bantuan dalam rangka pemenuhan kebutuhan tersebut. Adapun dalam rangka menjalankan agama, tentunya harus ditunjang dengan adanya sarana peribadatan yaitu masjid, musalla, terdiri dari 4 (empat) masjid. Di lihat dari jumlah masjid di atas cukup membuktikan bahwa masyarakat Kelurahan Manisa adalah mayoritas beragama Islam.

\section{Keadaan Pendidikan}

Masalah pendidikan di Kelurahan Manisa adalah bagian integral dari sistem pendidikan Nasional yang berdasarkan Pancasila dan Undang-Undang

${ }^{13}$ http://manisa.raz.web.id/hal-monografi.html. diakses pada tanggal 17 Juni 2019. 
Dasar 1945 yang bertujuan untuk meningkatkan iman dan takwa terhadap Tuhan Yang Maha Esa, kecerdasan, keterampilan, budi pekerti, kepribadian dan semangat kebangsaan, sehingga dapat menumbuhkan manusia-manusia pembangunan yang mampu membangun dirinya sendiri serta bersama-sama bertanggug jawab atas pembangunan bangsa. Dalam rangka mencerdaskan bangsa serta meningkatkan partisipasi sekolah, maka kebutuhan penduduk tentunya harus diimbangi dengan penyedian sarana dan prasarana pendidikan, baik pendidikan formal maupun non formal. Adapun lembaga pendidikan yang tercatat di Kelurahan Manisa adalah terdiri dari 3 (tiga) sekolah dasar (SD) dan 3 (tiga) taman kanak-kanak (TK). ${ }^{14}$

\section{Bentuk Tradisi Ziarah Kubur Setelah Melangsungkan Pernikahan pada Masyarakat Kelurahan Manisa Kecamatan Baranti Kabupaten Sidenreng Rappang}

Pernikahan dalam adat Bugis sesuatu yang sangat disakralkan, masyarakat sangat mengeramatkan acara pernikahan. Dalam kebiasaan sebagian masyarakat Bugis ketika ingin mengadakan suatu acara seperti acara pernikahan, atau mendirikan rumah atau akikah anak, menurut kebiasaan adat setempat, orang yang akan mengadakan acara harus meminta restu kepada nenek moyang yang telah tiada. Menurut kepercayaan masyarakat, tanpa restu nenek moyang biasa terjadi hal-hal yang tidak diinginkan dalam acara yang diadakan, misalnya ada keluarga mereka yang kecelakaan, tiba-tiba sakit, atau ada salah satu anggota keluarga yang tiba-tiba kesurupan.

Berdasarkan hasil penelitian yang dilakukan oleh penulis selama berada di lapangan, didapatkan berbagai informasi mengenai ziarah kubur setelah melangsungkan pernikahan pada masyarakat di Kelurahan Manisa Kecamatan Baranti Kabupaten Sidenreng Rappang. Dalam proses pernikahan, masih mengikuti adat istiadat di kalangan Bugis secara umum, dari awal acara pernikahan sampai akhir acara, namun ada tradisi yang menjadi rangkaian dari acara pernikahan yaitu ziarah kubur setelah acara resepsi pernikahan. Ziarah kubur dilakukan kedua mempelai pengantin yaitu dengan menziarahi kuburan keluarga kedua mempelai, baik dari keluarga mempelai laki-laki maupun keluarga mempelai wanita sebagai tanda rasa syukur dan meminta keberkahan karena acara pernikahannya telah berjalan dengan lancar.

Kebiasaan masyarakat kelurahan Manisa yang melakukan ziarah kubur setelah melangsungkan pernikahan sudah menjadi tradisi di kalangan masyarakat. Tradisi ini sudah ada sejak ratusan tahun dan dilakukan secara turun temurun dari nenek moyang mereka sampai sekarang, serta tradisi ini telah dicontohkan oleh tokoh spiritual terdahulu. Sebagaimana yang dikatakan oleh Bapak Ahmad sebagai tokoh agama sekaligus takmir masjid yang memahami tentang ziarah kubur ini:

Iye massiara kibburu purani isyariatkan Nabitta, jadi idi umma'na Nabi Muhammad isunnahkan ki makkacio okko Nabitta. Naiyakiyah salah siddi sunnah Nabitta iyanaritu massiara kibburu, isiarai kibburu na kelurga-ta, dena ipigau bawang nerekko degage

${ }^{14}$ http://manisa.raz.web.id/hal-monografi.html. Diakses pada tanggal 17 Juni 2019. 
contoh na pole okko ulama-ta, Ulama iye pigaui naidi makkacioki okko ulama-ta, na iye massiara kibburu napigaui tau purae botting marratu taung ni labe'e lettu makkukkue, iye tradisi massiara kibburue harus ipigau nasaba purani nacontohkan ulama-ta mappura laloe. $^{15}$

Artinya: Ziarah kubur telah disyariatkan oleh Rasulullah saw. berarti kita sebagai umat Nabi Muhammad saw. disunahkan untuk melakukannya yaitu dengan menziarahi keluarga kita yang telah meninggal dunia, adapun ziarah kubur yang kita lakukan setelah acara resepsi pernikahan sudah ada contohnya dari ulamaulama terdahulu sejak ratusan tahun lalu, sampai sekarang tradisi ini tetap kita pertahankan karena sudah dicontohkan oleh ulama kita dan kita mengikuti apa yang dilakukan oleh orang yang terdahulu dari kita.

Hal ini sejalan dengan yang dinyatakan oleh Ye' Laini, salah seorang tokoh masyarakat yang menyatakan bahwa:

Massiara kibburu'e marratu-ratu taunni ipigau, mancaji kebiasaan ni ipigau iye tradisi'e iyeko purani mappigau iyaregi masara, salah siddinna narekko purani botting taue makanja narekko laoi massiara kibburu, nasiarai kibburu na keluargana, iye massiara kibburu'e ko puraki botting harus tuliipigau, apalagi laoki massiara kibburu engaka tujuanna, iyenaritu maringerrang ki okko keluarga-ta mate'e, namancaji papparingerrang lao okko idi, makkada iye tau'e pasti mate. Jaji massiara kibburu'e de namarigaga ipigau nasaba iye anu makanja ipalao. ${ }^{16}$

Artinya: Ziarah kubur ini sudah ada sejak ratusan tahun lalu dan sudah menjadi kebiasaan kita melakukannya setelah mengadakan hajatan, salah satunya pernikahan. Ziarah kubur ini tidak bisa kita tinggalkan apalagi kita datang berziarah hanya untuk mendoakan si mayit dan mengingatkan kita akan kematian. Jadi saya rasa ziarah kubur ini tidak apa kita lakukan bahkan menjadi suatu kebaikan.

\section{Tujuan Ziarah Kubur Setelah Melangsungkan Pernikahan}

Ziarah kubur dilakukan oleh kedua pengantin setelah resepsi pernikahan hanya bertujuan untuk mengingatkan akan kematian. Selain itu, juga memperkenalkan kepada pasangan pengantin terhadap keluarga yang telah meninggal. Hal ini dikatakan oleh salah satu tokoh masyarakat yang bernama Ye' Laini di Kelurahan Manisa menyampaikan bahwa ziarah kubur setelah melangsungkan acara pernikahan memang merupakan suatu keharusan, karena tujuan dari ziarah kubur ini baik di antaranya:

\footnotetext{
${ }^{15}$ Ahmad, (57 tahun), Tokoh agama dan Ta'mir Masjid Nurul Yaqin Manisa, Wawancara, Manisa Kecamatan Baranti Kabupaten Sidenreng Rappang, 12 Mei 2019.

${ }^{16} Y$ e' Laini (67 tahun), Tokoh Masyarakat, Wawancara, Manisa Kecamatan Baranti Kabupaten Sidenreng Rappang 14 Mei 2019.
} 
1. Untuk mengingatkan kedua mempelai akan adanya kematian.

2. Untuk menunjukkan letak kuburan keluarganya kepada pasangan dan keluarga pasangan.

3. Sebagian juga datang berziarah untuk meminta doa restu dari nenek moyang mereka karena mereka beranggapan tanpa doa restu nenek moyang akan ada sesuatu yang tidak diinginkan terjadi baik sebelum pernikahan maupun setelah pernikahan. ${ }^{17}$

\section{Waktu dan Tempat Pelaksanaan Tradisi Ziarah Kubur}

Berkaitan dengan waktu pelaksanaan tradisi ziarah kubur ialah disesuaikan dengan kesempatan kedua keluarga mempelai, baik dari keluarga mempelai wanita maupun keluarga mepelai pria, sebagaiamna yang dikatakan oleh ibu Sakka, ibu pengantin yang mengatakan bahwa:

Iye massira kibburu'e de namattentu wettunna, tergantung padapireng na bottingnge sibawa keluargana, biasa ipigau sesso atau dua esso setelah acara botting, narekko duanggesso purana akad nikah nappa engka padapireng na, nappa wedding ipigau. Tapi biasanna keluargana makkunrai mariolo pigaui massiara kibbur'e nasaba biasa masija selesai acarana, iyeko purani nasiarai kibburuna keluargana makkunrai nappa botting makkunrai lao siarai kelurgana uronewe. $^{18}$

Arinya: Ziarah kubur ini tidak menentu waktunya, kapan ada waktu kedua mempelai 1 hari atau 2 hari setelah acara pernikahan baru bisa dilaksanakan, jika memang dua hari setelah akad nikah mereka memiliki waktu luang untuk berziarah kubur, maka pada hari itu juga baru dapat dilaksanakan. Namun, biasanya keluarga dari pihak mempelai wanita yang terlebih dahulu melaksanakan ziarah kubur, karena pesta wanita lebih cepat selesai, kemudian disusul oleh keluarga laki-laki.

Terkait dengan rentan waktu pelaksanaan tradisi ini, karena peziarah biasanya berziarah dari satu kuburan ke kuburan yang lain, biasanya membutuhkan waktu satu hari sampai dua hari unt uk melaksanakan tradisi ziarah kubur, satu hari dilaksanakan oleh pihak keluarga wanita dengan mengunjungi kuburan keluarga wanita, kemudian setelah semuanya selesai diziarahi, diperlukan satu hari lagi untuk mengziarahi kuburan keluarga laki-laki.

Berkaitan dengan lokasi tradisi ziarah kubur dilaksanakan, para peziarah mengunjungi pekuburan tempat di mana orang tua atau kerabat kedua pasangan pengantin dikuburkan, biasanya di pekuburan kampung mempelai laki-laki dan wanita, bahkan sebagian mereka melakukan safar untuk berziarah kubur di luar wilayah kampung mereka.

${ }^{17}$ (Ye Laini, Wawancara, 2019)

${ }^{18}$ Isakka (63 tahun), Ibu Pengantin Mempelai Laki-laki, Wawancara, Manisa Kecamatan Baranti Kabupaten Sidenreng Rappang 14 Mei 2019. 


\section{Persiapan yang Dipenuhi Sebelum Berangkat ke Kuburan}

Terkait persiapan yang disiapkan peziarah sebelum berangkat ke kuburan, bagi orang umum yang tidak terlalu kental adat istiadatnya cukup membawa air, kembang dan bunga pandan. Adapun masyarakat yang kental adatnya seperti keturunan Raja atau Bangsawan mereka melakukan safar ke tempat yang dikeramatkan seperti ke daerah Wajo yang berlokasi di Kec. Pammana ataukah di daerah Paleteang kab. Pinrang, mereka menyiapkan minyak baut digunakan untuk menyiram kuburan yang dikeramatkan tersebut.

Untuk masyarakat yang lebih kental adatnya setelah melangsungkan hajatan seperti pernikahan peziarah biasanya menyiapkan sesembelihan dari ayam ataukah kambing yang dijadikan sebagai sesembahan untuk nenek moyang mereka sebagai rasa syukur mereka acaranya berjalan dengan lancar. Untuk sesembelihan ayam atau kambing mereka mempersiapkan masakan-masakan orang terdahulu seperti Balunrang (ketupat yang terbuat dari daun janur) dengan bilangan-bilangan tertentu kadang 41 buah atau lebih. Menurut tradisi mereka semakin tinggi derajat mereka, maka semakin banyak balunrang yang disiapakan dan disertai dengan lauk-pauk seperti ikan, sayur-sayuran dan sebagainya. Setelah mereka sampai disana mereka menyembelih dan mengadakan selamatan di tempat tersebut.

Adapun orang yang terlibat dalam tradisi ziarah kubur ini yaitu keluarga terdekat dari pengantin seperti ibu, bapak sepupu dan kerabat terdekat mereka baik dari keluarga mempelai laki-laki maupun keluarga mempelai wanita. Bahkan biasanya ada di antar mereka yang datang berziarah dengan satu mobil penuh atau dua mobil jika berziarah kubur di tempat yang jauh.

\section{Doa Khusus Sebelum Masuk Area Pekuburan dan Saat Sampai di Pekuburan}

Menurut Narasumber yang bernama Pak Ahmad, doa khusus yang dibaca oleh para peziarah sebelum masuk di area pekuburan yaitu sesuai dengan apa yang dicontohkan Rasulullah saw., dengan membaca doa masuk pekuburan. Adapun setelah selesai menyirami kuburan, ada doa khusus yang hendak dibaca para peziarah, sebagaimana yang dikatakan pak Ahmad sebagai seorang takmir Masjid Nurul Yaqin Kelurahan Manisa, beliau berkata:

Narekko mattamaki kibburu'e de natomattama bawang, engka ibaca iyanaritu baca doa narekko tamai ki kibburu'e, iye paddoangge perellu iyapala nasaba yuli ibaca iyeko laoki massiara kibburu, naiye doa pura ni nappagguruang Nabitta "assalamu alaikum ya ahlal qubur', iyeko purani ibaca laoni sappai kibburuna keluarga ta, nappa ibolo wae ipasicampuru daun pandang, iyeko purani iyero idoakan, ekka paddoangeng mabiasa ibaca iyanaritu ibacangngi doa-doa maponco pole okko akoranggnge nappa itutu paddoangang ibaca al-Fatihah. ${ }^{19}$

Artinya: Kalau kita masuk kuburan kita tidak sembarang masuk, ada doa yang

${ }^{19}$ (Ahmad, Wawancara, 2019) 
harus dibaca terlebih dahulu, seperti biasanya doa masuk ke area pekuburan "assalāmu 'alaikum yā ahla al-qubūr", setelah itu kita cari kuburan keluarga pengantin dan menyiraminya dengan air yang dicampur dengan daun pandan kemudian didoakan si mayit, ada doa yang biasa dibaca yaitu dengan membaca surah pendek seperti membaca surah al-kautsar, bisa ditambah dengan surah-surah pendek yang lain dan ditutup dengan surah al-Fatihah.

Setelah penulis mewawancarai beberapa masyarakat, penulis mendapat informasi dari salah satu warga di kelurahan Manisa yang bernama Pak Ahmad seorang takmir masjid Nurul Yaqin Kelurahan Manisa terkait tata cara pelaksanaan ziarah kubur setelah melangsungkan pernikahan yang ada pada masyarakat Kelurahan Manisa Kecamatan Baranti Kabupaten Sidenreng Rappang yaitu: ${ }^{20}$

Menziarahi kuburan keluarga kedua mempelai pengantin; mempelai wanita bersama mempelai pria berangkat sama-sama menuju kuburan keluarga wanita untuk ziarah kubur, setelah semuanya selesai, si mempelai laki-laki lagi yang ikut bersama keluarga wanita berziarah kubur di kuburan keluarga laki-laki sampai selesai.

Menyiapkan persiapan sebelum berangkat ziarah kubur, hal-hal yang perlu dipersipakan sebelum berangkat ziarah kubur seperti daun pandan, bunga dan cerek tempat air.

Berwudhu terlebih dahulu sebelum berangkat ke kuburan; sebelum berangkat ke kuburan untuk ziarah kubur hedaknya kedua mempelai laki-laki dan wanita beserta keluarga yang ikut serta dalam tradisi ziarah kubur tersebut berwudhu terlebih dahulu untuk menjaga kebersihan tubuh.

Mengucapkan salam kepada ahli kubur, Di antara tata cara ziarah kubur di kalangan masyarakat Kelurahan Manisa adalah mengucapkan salam sebelum masuk di area pekuburan dan ini sesuai dengan sunah Rasulullah saw., beliau saw. mengajarkan umatnya untuk mengucapakan salam yang juga sekaligus doa ketika masuk ke dalam area pekuburan. Berikut bunyi doanya;

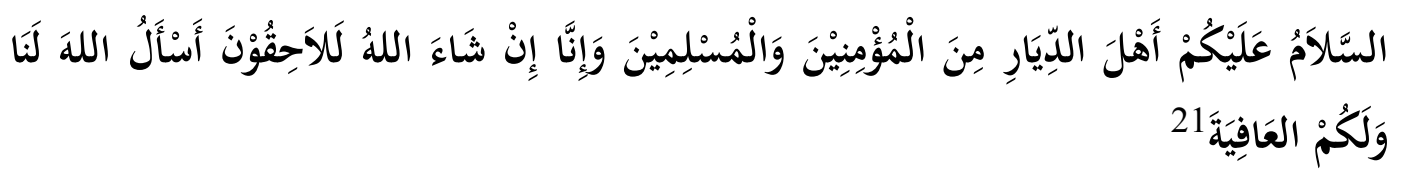

Artinya: Semoga keselamatan tercurah bagi penghuni kubur, dari kalangan orangorang mukmin dan muslim, dan kami insya Allah akan menyusul kalian semua. Saya memohon kepada Allah bagi kami dan bagi kalian keselamatan.

Doa di atas dianjurkan untuk dibaca sebelum masuk di area pekuburan, ketika berziarah kubur karena Rasulullah saw. selalu membaca doa tersebut ketika mengunjungi kuburan.

\footnotetext{
${ }^{20}$ (Ahmad, Wawancara, 2019)

${ }^{21}$ Abu Husain Muslim bin al-Ḥajjāj al-Qusyairī al-Naisābūrī, Śạịḥ Muslim, al-Qāhirah: Dār ibn al-Jauzī, 2009.h. 
Menyirami kuburan yang diziarahi dengan air dicampur dengan daun pandan; setelah masuk di area pekuburan para peziarah mencari kuburan keluarganya, setelah itu menyirami air yang telah dicampur dengan daun pandan. Menurut masyarakat setempat dengan menggunakan daun pandan bisa memberikan bau yang harum pada kuburan. Adapun untuk kuburan yang dikeramatkan disiram dengan minyak bau. Tidak mesti kedua pasangan suami istri yang menyirami kuburan tersebut bisa juga diwakili oleh pihak keluarga kedua mempelai, cukup keduanya menyentuh kuburan saat disiram atau yang telah disiami air oleh keluarganya.

Menghadap ke kiblat saat berdoa untuk keluarga yang diziarahi dan membaca zikir, tata cara selanjutnya setelah kuburan disirami dengan air dan daun pandan atau minyak baut para peziarah menghadap ke kiblat dan berdoa untuk si mayit.

Mengirimkan doa untuk si mayit, setelah itu membaca doa yang dikhususkan untuk si mayit, dianjurkan untuk peziarah membaca surah-surah pendek seperti surah al-Kautsar, al-Ikhlas, al-Falaq, al-Nās dan ditutup degan surah al-Fatihah yang ditujukan untuk si mayit.

\section{Tinjauan Hukum Islam Terhadap Tradisi Ziarah Kubur Setelah Melangsungkan Pernikahan}

Ziarah kubur setelah melangsungkan pernikahan pada masyarakat Sidenreng Rappang khususnya di Kelurahan Manisa adalah suatu hal yang dianggap kebiasaan masyarakat yang sudah mendarah daging pada sebagian masyarakat. Dalam masalah ziarah kubur, sesungguhnya Islam telah mengatur sedemikian rupa dan telah dicontohkan oleh Rasulullah saw. Dalam ziarah kubur yang dilakukan oleh sebagian masyarakat suku Bugis di Kelurahan Manisa tampak timbul hal-hal yang bertentangan dengan syariat. Masyarakat hanya melakukan ziarah kubur pada waktu dan tempat-tempat tertentu, seperti di kuburan para ulama atau yang ditokohkan masyarakat setempat sehingga menjadi adat kebiasaan di kalangan mereka tatkala berziarah setelah mengadakan hajatan.

Contoh, ziarah kubur yang dilakukan oleh kedua pasangan suami istri beserta keluarganya setelah melangsungkan resepsi pernikahan dengan mengunjungi kuburan keluarganya yang telah meninggal dunia. Tujuannya untuk meminta doa restu, pertolongan, keberkahan, dan sebagainya, sehingga adat ini sudah menjadi 'urf(kebiasaan) di tengah masyarakat Bugis, terkhusus masyarakat Sidrap.

Sedangkan hal yang disyariatkan oleh Rasulullah saw., bahwa ziarah kubur dilaksanakan kapan saja, tidak menentu waktunya, kapan saja bisa dilaksanakan, karena Rasulullah saw. mencontohkan hal tersebut ketika Rasulullah saw. menziarahi kuburan para syuhada yang bertujuan untuk mendoakan para sahabat di pekuburan Baqī, Rasulullah saw. berziarah pada malam hari. Hal ini diceritakan oleh Aisyah ra., yang berbunyi; 


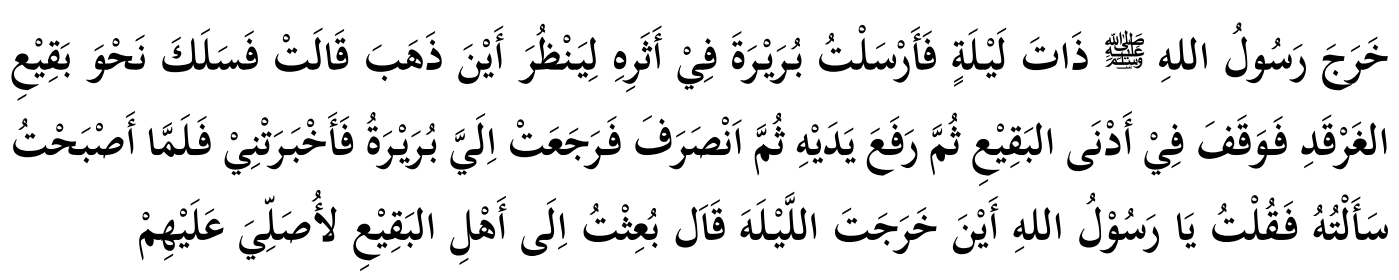

Artinya: Rasululullah saw. keluar pada suatu malam, maka aku (Aisyah) mengutus Barirah untuk membuntuti kemana beliau pergi, maka Rasulullah saw. mengambil jalan ke arah Baqī' al-Garqad kemudian beliau berdiri pada sisi yang terdekat dari Baqì' lalu beliau mengangkat tangannya, setelah itu beliau pulang, maka kembalilah Barirah kepadaku dan mengabariku apa yang dilihatnya. Maka pada pagi hari Aku bertanya dan berkata, Wahai Rasulullah, keluar kemana engkau semalam? Beliau berkata, Aku diutus kepada penghuni Baqī' untuk mendoakan mereka.

Dari hadis di atas menunjukkan bahwasanya ziarah kubur dapat dilaksanakan kapan saja, tidak ditentukan waktunya dan dari apa yang dilakukan Rasulullah saw. menunjukkan bahwasanya ziarah kubur disunahkan pada malam hari. Hal yang disyariatkan Rasulullah saw. ketika berziarah kubur adalah agar dapat mengingat akhirat dan kematian, mengambil nasihat dan pelajaran dari kondisi yang diziarahinya, serta mendoakannya dan meminta rahmat kepada Allah swt. untuk orang yang sudah meninggal, sehingga orang yang berziarah tersebut menjadi orang yang telah berbuat baik kepada orang yang sudah meninggal.

Ziarah kubur dalam Islam yang diperbolehkan tentu memiliki syarat-syarat tertentu yang harus dilakukan sebagai bentuk menghindari perbuatan syirik. Hal ini mengingat bahwa manusia bisa saja berpaling dan menghindar dari ajaran Allah dikarenakan hawa nafsunya dan godaan setan terhadap manusia. Untuk itu, berikut syarat agar tidak mudah terbawa pada kesyirikan.

Tidak Menjadikan Kuburan Sebagai Benda Keramat, ziarah kubur tentu tidak boleh membuat seorang muslim yang pada akhirnya menganggap bahwa kuburan atau mayit yang ada di dalamnya memiliki kekuatan gaib, supernatural, dapat menolong atau membantu mengabulkan doa. Kuburan dalam ziarah kubur tidak boleh dijadikan sebagai benda keramat, walaupun tetap menganggap Allah sebagai Ilah, dan jika masih tetap menganggap kuburan sebagai keramat, maka potensi menuju kepada praktik syirik juga sangat besar.

Syirik dalam Islam adalah perbuatan yang sangat dibenci oleh Allah swt., sedangkan perbuatan syirik tidak akan diampuni sebelum manusia benar-benar melakukan taubatan nasuha dan memohon ampunan dengan sungguh-sungguh kepada Allah swt. Allah swt. adalah Maha Segalanya, sedangkan jika manusia menganggap ada hal lain di mana mereka dianggap sebagai sesuatu yang dapat memberikan pertolongan dalam hidupnya, di segala aspek, maka hal tersebut bisa membuat kita mempersekutukan Allah swt. Lama kelamaan praktik tersebut

${ }^{22}$ Ahmad Bin Hanbal, al-Musnad, Cet. IV; Beirūt: Lebanon Dār al-Maktabah al-Islāmiyah 1403. h. 96. 
membuat manusia justru lupa akan kekuasaan dan keesaan Allah swt.

Tidak Meminta Doa atau Permohonan pada Kuburan atau yang Sudah Meninggal; ketika melakukan ziarah kubur tentu tidak diperbolehkan untuk meminta doa atau permohonan kepada kuburan atau orang yang sudah meninggal. Allah swt. sudah menyuruh kepada manusia bahwa berdoalah kepada Allah maka Allah akan mengabulkannya. Hal ini semata-mata karena Allah adalah zat Maha Agung yang mudah sekali untuk mengabulkan doa manusia. Untuk itu, tidak diperkenankan manusia memohon kepada selain Allah. Perbuatan memohon kepada selain Allah swt. tentu sangat irasional atau tidak masuk akal, karena sesama makhluk atau benda mati yang sejatinya adalah makhluk lemah tidak mungkin bisa jadi tempat bergantung hidup.

Tidak Memberikan Sesajen atau Sesembahan; memberikan sesajen atau sesembahan adalah bagian dari praktik kesyirikan karena hal tersebut merupakan bagian dari sesembahan atau pengibadahan terhadap sesuatu. Untuk itu, di dalam ziarah kubur dilarang untuk memberikan apapun pada kuburan atau mayit. Cukup mendoakannya dan kita bisa merenung untuk menghayati bahwa kematian sangatlah dekat dengan manusia. Bukan seperti yang dilakukan sebagian masyarakat di Kelurahan Manisa, mereka melakukan ziarah kubur bertujuan untuk meminta keberkahan dan doa restu dari kedua orang tua pegantin, tentunya ini bertentangan dengan syariat dan terdapat di dalamnya unsur kesyirikan. ${ }^{23}$

Ada beberapa unsur kesyirikan yang penulis temukan dalam tradisi ziarah kubur ini adalah: yang pertama, sebagian masyarakat melakakukan ziarah kubur setelah melangsungkan pernikahan untuk meminta keberkahan dari hajatan mereka, kelanggengan rumah tangga dan doa restu dari keluarga mereka yang telah meninggal dunia. Sebagian mereka berziarah kubur karena rasa takut, ketika tidak berziarah kubur akan terjadi hal yang tidak diinginkan ataukah ketika kedua mempelai tidak mengadakan ziarah kubur, keluarga mereka selalu terganggu sehingga mempengaruhi kelanggengan rumah tangganya. Tentunya hal ini tanpa mereka sadari telah terjatuh dalam kesyirikan karena rasa takut dan pengharapan hanya untuk Allah swt. tanpa selain-Nya. Seakan-akan mereka meminta pada tradisi ini untuk terhindarkan dari berbagai malapetaka. Mereka tidak memohon kepada Allah swt. perlindungan terhadap gangguan dan penyakit, mereka lupa bahwa yang mampu menghilangkan gangguan dan penyakit adalah hanya Allah swt. Sebagaimana firman Allah swt. dalam surah al-An'am/6: 17.

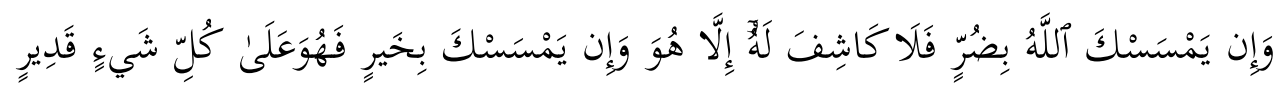

Terjemahnya: "Dan jika Allah menimpakan sesuatu kemudharatan kepadamu, maka tidak ada yang menghilangkannya melainkan Dia sendiri. Dan jika Dia mendatangkan kebaikan kepadamu, maka Dia Maha Kuasa atas segala sesuatu."24

Dalam ayat ini menunjukan bahwa hanya Allah swt. yang dapat

\footnotetext{
${ }^{23}$ Baetī Salām al-Bantānī, Ziarah al-Qubūr 'alā Hadyi Rasūlullah, Ziarah al-Qubūr 'alā (Hadyi Rasūlullah. alQassīm: Maktab Da'wah, 2010). h. 41-48.

${ }^{24}$ Kementerian Agama Republik Indonesia, al-Qur'an Tajwid dan Terjemahnya, h.129.
} 
memberikan keburukan dan kebaikan kepada seseorang dan tidak ada satu makhluk pun yang mampu melakukannya. Demikian juga Firman Allah swt dalam surah al-Taubah/51: 9 .

$$
\text { قُل لَّن يُصِيبنَا إلَّلا مَا كَتَبَ آللَّهُ لَنا.... }
$$

Terjemahnya: "Tidak akan menimpa kami melainkan apa yang telah ditetapkan Allah untuk kami."25

Dalam ayat ini menunjukan bahwa tidak perlu mengada-adakan sesuatu yang tidak disyariatkan oleh Allah swt. untuk terhindar dari keburukan yang ditimpakan oleh Allah kepada seseorang karena Allah swt. telah menetapkan apaapa yang akan menimpa seseorang dan tidak ada seorang pun yang dapat mencegahnya jika Dia menghendaki.

Unsur kesyirikan yang kedua, terkandung dalam tradisi zirah kubur ini bagi masyarakat yang kental adatnya seperti keturunan Raja atau Bangsawan, mereka melakukan ziarah kubur di tempat yang dikeramatkan seperti di Puttuang di Desa Sipodeceng, mereka menyiapkan minyak baut yang digunakan untuk menyiram kuburan yang dikeramatkan tersebut. Demikian juga sebagian mereka ada yang menyembelih ayam atau kambing untuk nenek moyang mereka sebagai rasa syukur mereka lantaran acaranya berjalan dengan lancar.

Unsur kesyirikan yang ketiga, terkandung dalam tradisi ziarah kubur ini adalah masyarakat menganggap bahwa ziarah kubur ini adalah sesuatu yang wajib dilakukan oleh kedua pasangan pengantin setelah melangsungkan pernikahan dengan dalil mengikuti nenek moyang, bahwa mereka mengikuti adat-istiadat atau tradisi nenek moyang mereka agar tetap lestari, di mana setiap yang dilakukan dalam tradisi ziarah kubur tersebut memiliki makna filosofis tertentu meskipun kedua pasangan pengantin tidak faham dengan apa yang dilakukan dan hal ini juga tidak pernah dicontohkan oleh Rasulullah saw.

Padahal Allah swt. memerintahkan untuk mengikuti perintah-Nya, namun perintah ini dilalaikan oleh sebagian hamba-hamba-Nya dengan mengatakan mereka mengikuti apa yang telah dikerjakan oleh nenek moyang mereka atau mempertahankan serta melestarikan tradisi nenek moyang mereka. Hal ini sebagaimana firman Allah swt. dalam surah al-Baqarah/1: 170.

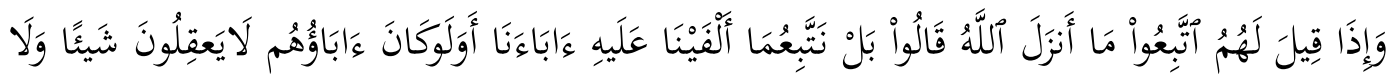

Terjemahnya: "Dan apabila dikatakan kepada mereka, ikutilah apa yang diperintahkan oleh Allah, mereka menjawab: '(Tidak), tetapi kami hanya mengikuti apa yang telah kami dapati dari (perbuatan) nenek moyang kami. (Apakah mereka akan mengikuti juga), walaupun nenek moyang mereka itu tidak mengetahui suatu apapun, dan tidak mendapat petunjuk."

Tradisi yang seperti ini tidak boleh dipertahankan karena akan

${ }^{25}$ Kementerian Agama Republik Indonesia, al-Qur'an Tajwid dan Terjemahnya, h. 195. 
mengundang murka Allah swt. sebab di dalamnya tedapat perbuatan kesyirikan yang kata Allah swt. adalah kezaliman yang besar, sebagaimana firman Allah swt pada surah Lukman/31: 13.

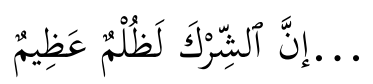

Terjemahnya: "Sesungguhnya kesyirikan itu adalah kezaliman yang besar." 26

Demikian juga Allah mengancam orang-orang yang berbuat kesyirikan, Adapun ancaman Allah di antaranya, Allah swt. tidak akan mengampuni orangorang yang menyekutukan Allah swt. (syirik) dan mengampuni dosa selainnya, sebagaimana firman Allah swt. dalam surah al-Nisa/4:48.

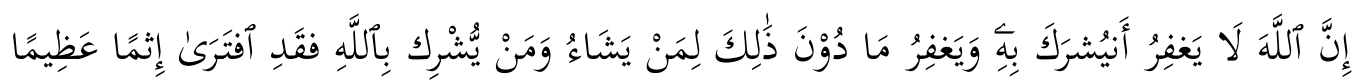

Terjemahnya: "Sesungguhnya Allah tidak akan mengampuni dosa syirik, dan Dia mengampuni segala dosa yang selain dari (syirik) itu, bagi siapa yang dikehendakiNya. Barangsiapa yang mempersekutukan Allah, maka sungguh ia telah berbuat dosa yang besar." 27

Kesyirikan juga diancam pelakunya oleh Allah swt. dengan mebatalkan seluruh amalan yang dikerjakan. Hal ini dijelaskan pada firman Allah dalam surah al-An'ām/6: 88.

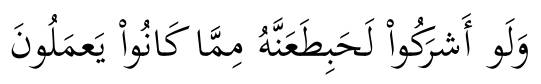

Terjemahnya: "Seandainyamereka mempersekutukan Allah, niscaya lenyaplah dari mereka amalan yang telah mereka kerjakan." 28

Bahkan Allah swt. mengancam orang yang menyekutukan Allah swt. (syirik) dengan mengharamkan syurga bagi pelakunya pada surah al-Ma'idah/5: 72.

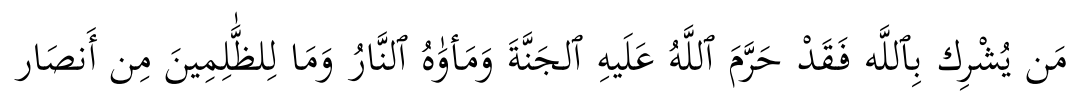

Terjemahnya: "Sesungguhnya orang yang mempersekutukan (sesuatu dengan) Allah, maka pasti Allah mengharamkan."29

Adapun unsur bidah yang terkandung dalam tradisi ini adalah pada penentuan waktu ziarah kubur yaitu setelah selesai acara pernikahan yang dilakukan oleh kedua pasangan pengantin dan ditemani keluarga kedua pengantin dan dalam proses ziarah kuburnya tidak sesuai dengan tutunan Rasulullah saw., sedangkan mengada-adakan suatu ibadah dalam Islam yang tidak ada dasarnya dalam al-Qur'an dan Sunah, maka itu adalah perkara bidah. Sebagaimana disebutkan dalam hadis Rasulullah saw. Dari 'Aisyah ra. bahwa Rasulullah saw.

\footnotetext{
${ }^{26}$ Kementerian Agama Republik Indonesia, al-Qur'an Tajwid dan Terjemahnya, h. 412

${ }^{27}$ Kementerian Agama Republik Indonesia, al-Qur'an Tajwid dan Terjemahnya, h. 86.

${ }^{28}$ Kementerian Agama Republik Indonesia, al-Qur'an Tajwid dan Terjemahnya, h. 138

${ }^{29}$ Kementerian Agama Republik Indonesia, al-Qur'an Tajwid dan Terjemahnya, h. 120.
} 
bersabda:

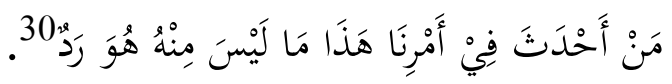

Artinya: "Barang siapa yang mengerjakan suatu amalan yang tidak kami perintahkan maka amalan itu tertolak."

Semua amalan yang tidak bersumber dari al-Qur'an dan sunah, maka amalan itu tertolak atau sia-sia, seperti tradisi yang dilakukan oleh masyarakat di Kelurahan Manisa yaitu tradisi ziarah kubur setelah melangsungkan pernikahan. Demikian juga Allah swt. berfirman dalam al-Qur'an yang memerintahkan manusia untuk mentaati Allah swt. dan Rasul-Nya, hal ini sebagaimana firman Allah swt. dalam surah Ali Imrān/3: 32.

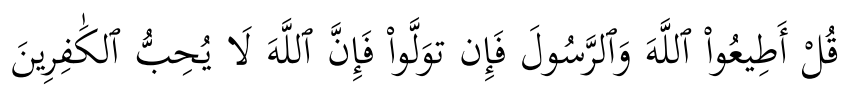

Terjemahnya: "Katakanlah: Taatilah Allah dan Rasul-Nya; jika kamu berpaling, maka sesungguhnya Allah tidak menyukai orang-orang kafir". ${ }^{31}$

Ayat ini mengandung makna bahwa jika seorang menyalahi atau menyelisihi perintah Allah swt. dan Rasul-Nya, maka dia telah kufur kepada Allah swt. dan Rasul-nya, dan Allah swt. tidak menyukai orang orang yang kufur. Dalam ayat lain Allah swt. juga memerintahkan hamba-hambanya untuk mengikuti apaapa yang datang dari Rasulullah saw. dan menjauhi apa-apa yang dilarang oleh Rasulullahi saw. hal ini terkandung dalam surah al-Hasyr/59: 7.

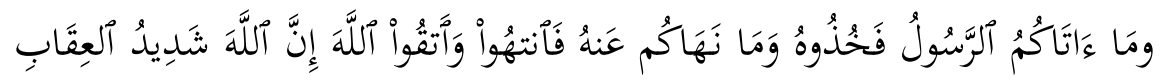

Terjemahnya: “Apa yang diberikan Rasul kepadamu, maka terimalah. Dan apa yang dilarangnya bagimu, maka tinggalkanlah. Dan bertakwalah kepada Allah. Sesungguhnya Allah amat keras hukumannya." 32

Ayat di atas mengandung makna bahwa setiap apa yang datang dari Rasulullah saw. maka kita harus turuti dan setiap yang dilarang maka kita wajib meninggalkannya.

Rasullah saw. telah mencontohkan tata cara ziarah kubur yang sesuai dengan syariat yang harus dilakukan oleh orang yang ingin berziarah kubur, berikut tata cara ziarah kubur yang dicontohkan Rasulullah saw.: ${ }^{33}$

1. Memberikan salam kepada penghuni kubur (muslimin) dan mendoakan kebaikan bagi mereka.

Di antara doa yang diajarkan oleh Rasulullah saw. kepada umat-Nya yang h. 184.

${ }^{30}$ Muhammad Bin Ismāīl Abū Abdillah al-Bukhārī, Śahịh Bukhārī, Juz III, (Cet. I;Dār Tūqu al-Najāh, 1422 H),

${ }^{31}$ Kementerian Agama Republik Indonesia, al-Qur'an Tajwid dan Terjemahnya, h. 54.

${ }^{32}$ Kementerian Agama Republik Indonesia, al-Qur'an Tajwid dan Terjemahnya, h. 546.

${ }^{33}$ Baetī Salām al-Bantānī, Ziarah al-Qubūr 'alā Hadyi Rasūlullah, h. 9-13. 
berziarah kubur, yaitu mengucapakan:

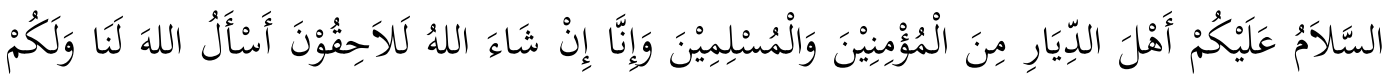

$$
\begin{aligned}
& \text { العَافِيَةَ }
\end{aligned}
$$

Artinya: Semoga keselamatan tercurah bagi penghauni kubur, dari kalangan orangorang mukmin dan muslim, dan kami insya Allah akan menyusul kalian semua. Saya memohon kepada Allah bagi kami dan bagi kalian keselamatan.

2. Dianjurkan untuk tidak mengenakan sandal ketika berjalan di atas kuburan. Hal ini berdasarkan hadis Basyīr bin Khașașiah ra. Rasulullah saw. bersabda:

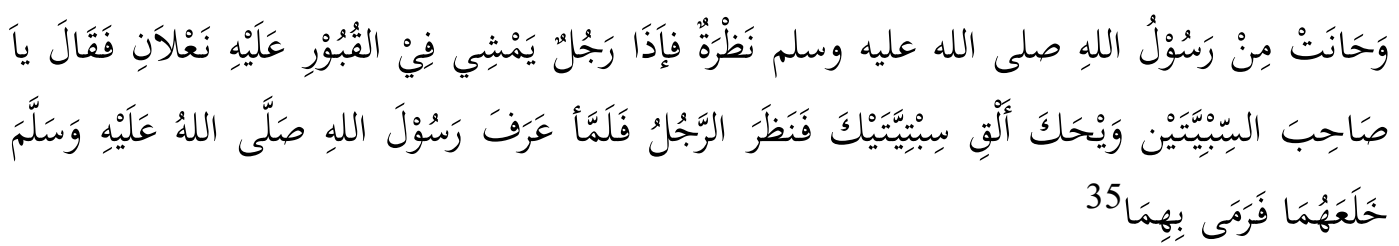

Artinya: Ketika Rasulullah saw. sedang berjalan, tiba-tiba beliau memandang seorang laki-laki yang berjalan di antara kubur dengan mengenakan sandal, maka Rasulullah saw. bersabda, Wahai pemilik (yang memakai) sandal celakalah engkau lepaskanlah sandalmu. Maka orang itu memandang tat kala dia mengetahui Rasulullah saw. ia melepaskan kedua sandalnya dan melemparkannya.

Berkata al-Hāfiz Ibnu Hajar, hadis ini menunjukkan makruhnya berjalan diantara kuburan dengan sandal. ${ }^{36}$ Berkata Syaikh al-Bānī ra. hadis ini menujukkan makruhnya berjalan di atas kuburan dengan memakai sandal. ${ }^{37}$

3. Tidak duduk atau bersandar pada kuburan.

Hal ini berdasarkan hadis Abū Marbad ra. dari Nabi saw., beliau bersabda:

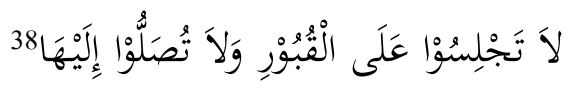

Artinya: "Janganlah kalian duduk di atas kuburan dan jangan melakukan salat ke arahnya."

Demikian juga hadis Abu Hurairah ra. bahwa Rasulullah saw. bersabda:

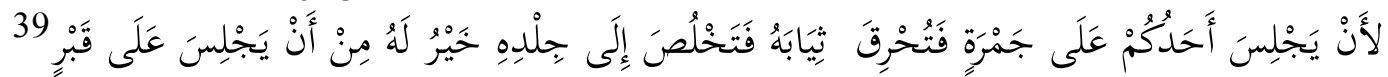

Artinya: Seandainya salah seorang dari kalian duduk di atas bara api hingga bara api itu membakar pakainnya sampai mengenai kulitnya itu adalah lebih baik

\footnotetext{
${ }^{34}$ Abu Husain Muslim bin al-Hajjāj al-Qusyairī al-Naisābūrī, Śahīh Muslim, h. 216.

${ }^{35}$ Ahmad Bin Hanbal, al-Musnad, h. 83.

${ }^{36}$ Baetī Salām al-Bantānī, Ziarah al-Qubūr 'alā Hadyi Rasūlullah, h. 10.

${ }^{37}$ Baetī Salām al-Bantānī, Ziarah al-Qubūr 'alā Hadyi Rasūlullah, h. 10.

${ }^{38}$ Abu Husain Muslim bin al-Hajjāj al-Qusyairī al-Naisābūrī, Śậ̄h Muslim, h. 972.

${ }^{39}$ Abu Husain Muslim bin al-Hajjāj al-Qusyairī al-Naisābūrī, Śạīh Muslim, h. 972.
} 
daripada dia duduk di atas kuburan.

Adapun maksud hadis di atas menunjukkan bahwa duduk di atas kuburan termasuk dosa besar karena ancamannya yang keras.

4. Dianjurkan tetap berdiri dan dibolehkan bagi peziarah untuk mengangkat tangannya ketika berdoa untuk penghuni kubur.

Berdasarkan hadis Aisyah ra.:

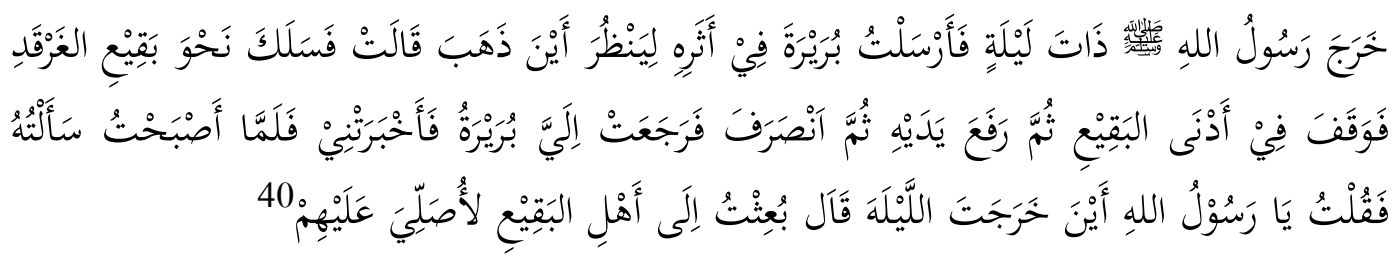

Artinya: Rasululullah saw. keluar pada suatu malam, maka aku (Aisyah) mengutus Barirah untuk membuntuti kemana beliau pergi, maka Rasulullah saw. mengambil jalan ke arah Baqī’ al-Garqad kemudian beliau berdiri pada sisi yang terdekat dari Baqì' lalu beliau mengangkat tangannya, setelah itu beliau pulang, maka kembalilah Barirah kepadaku dan mengabariku apa yang dilihat. Maka pada pagi hari Aku bertanya dan berkata, Wahai Rasulullah, keluar kemana engkau semalam? Beliau berkata, Aku diutus kepada penghuni Baqì' untuk mendoakan mereka.

5. Menghadap ke kuburan ketika memberi salam kepada penghuni kubur.

6. Ketika mendoakan penghuni kubur tidak boleh menghadap ke kuburan melainkan menghadap kiblat.

Dari tata cara ziarah kubur di atas, yang dilakukan oleh sebagian masyarakat di Kelurahan Manisa setelah mengadakan acara pernikahan, tampak ada sebagian amalan-amalan yang dilakukan masyarakat setempat yang tidak sesuai dengan tata cara ziarah kubur yang telah dicontohkan Rasulullah saw. (bidah) bahkan sebagian mereka berlebih-lebihan dalam berziarah kubur, sedangkan ziarah kubur menurut Islam hanyalah salah satu sarana agar seorang muslim selalu beriman dan mengingat kematian. Dengan ziarah kubur, umat Islam akan mengingat bahwa kematian itu nyata.

Ziarah kubur merupakan amalan sunah yang sangat dianjurkan dalam Islam, apalagi menziarahi makam orang tua sendiri, namun tidak dikhususkan pada waktu tertentu. Ziarah kubur termasuk ibadah yang mulia di sisi Allah swt. Sehingga Rasulullah menganjurkan umatnya untuk berziarah kubur. Sebagaimana sabda Rasulullah saw.:

\footnotetext{
${ }^{40}$ Ahmad Bin Hanbal, al-Musnad, h. 96.

${ }^{41}$ Abu Husain Muslim bin al-Hajajāj al-Qusyairī al-Naisābūrī, Śahịh Muslim, h. 216.
} 
Artinya: "Maka sekarang ziarahilah kuburan."

Hadis di atas menunjukkan akan anjuran dari Rasulullah saw. kepada ummatnya untuk berziarah kubur.

\section{KESIMPULAN}

Masyarakat Kelurahan Manisa setelah acara pernikahan mereka melakukan ziarah kubur dengan bentuk-bentuk seperti; menentukan waktu tertentu sesuai kesepakatan kedua mempelai, menyiapkan persiapan yang dibutuhkan seperti air, ceret dan daun pandan, berwudhu sebelum berangkat ke kuburan, berdoa sebelum masuk di area pekuburan, menyiram kuburan dengan air yang dicampur dengan daun pandan, kemudian kedua mempelai pengantin memegang batu nisan kuburan, mendoakan si mayit dengan membacakan surah-surah tertentu dan ditutup dengan surah Al-Fatihah.

Dalam Islam ziarah kubur disyariatkan akan tetapi dalam berziarah kubur harus sesuai dengan tuntunan Rasulullah saw., namun yang ditemukan di kalangan masyarakat Kelurahan Manisa tidak sesuai dengan apa yang dicontohkan oleh Rasulullah saw., seperti ziarah kubur yang mereka lakukan di waktu-waktu tertentu, menyiram kuburan dan meminta restu dari kuburan yang diziarahi.

\section{DAFTAR PUSTAKA}

Batanji, Ibnu. (2013). Bila Kuburan Didewakan, t. Cet; Solo: Pustaka Arafah.

Al-Bantānī, Baetī Salām. (2010). Ziarah al-Qubūr 'alā Hadyi Rasūlullah, alQassīm: Maktab Da'wah.

Bin Hanbal, Ahmad. (1403). Al-Musnad. Cet. IV; Beirūt: Lebanon Dār alMaktabah al-Islāmiyah.

Al-Bukhārī, Muhammad Bin Ismāīl Abu Abdillah. (1422). Śạịḥ Bukhān̄̄, Juz III, Cet. I;Dār Tūqu al-Najāh.

H. Hart, Michael. (1987). 100 A Rangking of The Most Influential Person In Histori, New York: Hart Pub. Co.

Ibnu Taimiyyah, Syaikh al-Islām. (1992). Ziyārah al-Qubūr wa al-Istinjā du bī alMaqbū ri, Cet. I; [t.t.] Dār al-Śahābah lī al-Tarāś.

Al-Naisābūrī, Abu Husain Muslim bin al-Hajjāj al-Qusyairī. (2009). Śahịḥ̣ Muslim, Cet. I; al-Qāhirah: Dār ibn al-Jauzī. 
BUSTANUL FUQAHA : Jurnal Bidang Kajian Islam

Vol. 1, No. 3 (2020) : Hal. 272-293

Website: https://journal.stiba.ac.id

Taufik. (2018). Persepsi Masyarakat Palakka Teradap Tradisi Ziarah Kuburan Petta Betta'e Di Kabupaten Bone (Suatu Tinjauan Teologis), Skirpsi, Universitas Islam Negeri Alauddin Makassar.

Al-Tirmiżì, Muḥammad bin Isā bin Surah (1417) Sunan al-Tirmidzi, juz I, Riyadh: Maktabah Ma'arif.

Al-Azdi, Abi Daud Sulaiman bin al-As'as al-Sijistani. (1997) Sunan Abi Daudjuz III, Beirūt: Dār Ibnu Hazm.

Isakka (63 tahun), Ibu Pengantin Mempelai Laki-laki, Wawancara, Manisa Kecamatan Baranti Kabupaten Sidenreng Rappang 14 Mei 2019.

Kementerian Agama Republik Indonesia. (2010). Al-Qur'an Tajwid dan Terjemahnya. t. Cet. Jakarta: Syamil Qur'an.

Mustami, Muhammad Khalifah. (2015). Metodologi Penelitian Pendidikan. Cet.I; Yogyakarta: Aynat Publishing.

Tim Penyusun Kamus Pusat Bahasa. (2008). Kamus Bahasa Indonesia, t. Cet; Jakarta: Pusat Bahasa Departemen Pendidikan Nasional.

Internet:

http://manisa.raz.web.id/hal-monografi.html. Diakses pada tanggal 17 Juni 2019.

\section{Wawancara Informan:}

Ahmad, (57 tahun), Tokoh agama dan Ta'mir Masjid Nurul Yaqin Manisa, Wawancara, Manisa Kecamatan Baranti Kabupaten Sidenreng Rappang, 12 Mei 2019.

Ye' Laini (67 tahun), Tokoh Masyarakat, Wawancara, Manisa Kecamatan Baranti Kabupaten Sidenreng Rappang 14 Mei 2019. 